\title{
Analysis of Casein Biopolymers Adsorption to Lignocellulosic Biomass as a Potential Cellulase Stabilizer
}

\author{
Anahita Dehkhoda Eckard, ${ }^{1}$ Kasiviswanathan Muthukumarappan, ${ }^{1}$ and William Gibbons ${ }^{2}$ \\ ${ }^{1}$ Department of Agricultural and Biosystems Engineering, South Dakota State University, 1400 North Campus Drive, Brookings, \\ SD 57007, USA \\ ${ }^{2}$ Department of Biology and Microbiology, South Dakota State University, 1400 North Campus Drive, Brookings, SD 57007, USA
}

Correspondence should be addressed to Anahita Dehkhoda Eckard, anahita.eckard@sdstate.edu

Received 23 May 2012; Accepted 3 July 2012

Academic Editor: Anuj K. Chandel

Copyright (C) 2012 Anahita Dehkhoda Eckard et al. This is an open access article distributed under the Creative Commons Attribution License, which permits unrestricted use, distribution, and reproduction in any medium, provided the original work is properly cited.

\begin{abstract}
Although lignocellulosic materials have a good potential to substitute current feedstocks used for ethanol production, conversion of these materials to fermentable sugars is still not economical through enzymatic hydrolysis. High cost of cellulase has prompted research to explore techniques that can prevent from enzyme deactivation. Colloidal proteins of casein can form monolayers on hydrophobic surfaces that alleviate the de-activation of protein of interest. Scanning electron microscope (SEM), fourier transform infrared spectroscopy (FT-IR), capillary electrophoresis (CE), and Kjeldahl and BSA protein assays were used to investigate the unknown mechanism of action of induced cellulase activity during hydrolysis of casein-treated biomass. Adsorption of casein to biomass was observed with all of the analytical techniques used and varied depending on the pretreatment techniques of biomass. FT-IR analysis of amides I and II suggested that the substructure of protein from casein or skim milk were deformed at the time of contact with biomass. With no additive, the majority of one of the cellulase mono-component, $97.1 \pm 1.1$, was adsorbed to CS within $24 \mathrm{~h}$, this adsorption was irreversible and increased by $2 \%$ after $72 \mathrm{~h}$. However, biomass treatment with skim-milk and casein reduced the adsorption to $32.9 \% \pm 6.0$ and $82.8 \% \pm 6.0$, respectively.
\end{abstract}

\section{Introduction}

Production of ethanol from residual lignocellulosic biomass may serve as a promising clean fuel substitute that can reduce the greenhouse gases, ease the resource limitations of fossil fuel, eliminate the concerns of using food for fuel production, progress the rural economy, and create direct and indirect jobs. The market of ethanol grew from less than a billion liters in 1975 [1], and it is expected to reach more than 22 million gallons by 2022 [2].

Carbohydrates of cellulose and hemicellulose are hydrolyzed with two routes of acid or enzymatic hydrolysis to their subunits that can be fermented to ethanol by, for example, baker's yeast [3]. Despite extensive research, the production of ethanol from lignocellulosic biomass in a manner that can economically compete with that of corn has not yet been achieved.
The cost of cellulolytic enzymes remains one of the key challenges for second-generation biofuel production. In a recent study, the price of cellulytic enzymes has been estimated to be $\$ 0.68 /$ gal ethanol [4]. Considering that the price of enzyme in dry-grind corn ethanol is only 0.03-0.04\$/gal ethanol [5], an extensive price gap must be diminished before lignocellulosic ethanol can compete with corn ethanol process. Enzymes have been found to be deactivated by a variety of reasons such as thermal effects imposed in a longer process [6], shearing effect [7], airliquid contact [8], irreversible adsorption to active (e.g., cellulose) and nonactive sites (e.g., lignin) [9-12] and high concentrations of monomer sugars of hemicellulose (i.e., xylose, mannose, and galactose) [13, 14], xylo-oligomers [13], soluble lignin or lignin degradation products [15, 16], polymeric phenol tannic acids, and to a lesser extent monomeric phenolic compounds [17]. 
Cellulase deactivation can reach to as low as $16 \%$ of the initial activity within the first $24 \mathrm{~h}$ of hydrolysis [9]. Deactivation of cellulase is certainly a negative property that impacts the process cost by eliminating the chance of enzyme recycling or requiring more enzymes to maintain acceptable conversion rates.

In addition to efforts to genetically engineer new types of enzymes and enzyme producing microbes, application of surfactants (especially the nonionic) showed to be an effective approach to improve enzyme activity and hence reduce their application rate or increase the possibility for recycling. When surfactants are present in solution at levels beyond the critical micelle concentration (CMC), core-shell nanoparticles are formed. The interactions between enzymes and these micelle particles can result in a strong positive modification of the catalytic properties of the enzyme, such that "superactivity" of enzymes can be observed. Thus, an enhanced catalytic reaction can occur at the interface of micelles enzyme compared to that in aqueous phase [18]. It was suggested that the electrostatic interaction between micelle and enzyme, such as lipase, activates the key amino acids of enzyme (e.g., lysine and arginine) resulting in increased catalytic activity [19]. Also it was suggested that surfactants adsorb in the monomer form [20] to the surface of lignocellulosic biomass and prevent irreversible enzyme adsorption by increasing entropy at the time of contact with enzyme, thus increasing the amount of free enzyme in solution [21, 22]. Disruption effect of biomass (e.g., removal of lignin, disruption of H-bonding in cellulose, and removal of amorphous cellulose) was reported to be another potential effect of surfactants [14, 20, 23].

Although surfactants have demonstrated these potential advantages, amphiphilic polymers of proteins and biopolymers are better choices in improvement of enzyme activity. This is because surfactants might have disadvantages such as foaming property and environmental pollution [24], and in some cases even small quantities of Tween 80 have been shown to be inhibitory to some strains of yeast [25]. For instance, application of $2.5 \mathrm{~g} / \mathrm{L}$ Tween 20 helped to reduce the enzyme loading by $50 \%$, while retaining cellulose conversion [11]. However, $1 \mathrm{~g} / \mathrm{L}$ of Tween 20 was found to be an inhibitor to D. claussenii [26].

Alternative lignin-blocking polypeptides that were reported to enhance the catalytic reaction of cellulase by several folds include soybean meal, corn steep liquor, bovine serum albumin (BSA), amylase, chicken egg albumin, and combinations thereof [12]. The high cost of some of these proteins, such as BSA, has prompted us to further investigate more cost-efficient protein sources to be used as an enzyme activator.

Recently, we found for the first time that casein can be a good alternative stabilizer for cellulase, depending on the type of casein used (e.g., ultrafiltered liquid, lyophilized acid casein [27], and complete casein (gluten free)). In our recent study, it was found that casein can increase the ethanol yield from corn stover by as much as $8.48 \%-33.7 \%$ through enhancement of enzyme activity. However, the mechanism of action behind the effectiveness of casein during hydrolysis and fermentation of lignocellulosic biomass remained a question. Application of casein as a stabilizer for protein structure or even as a chaperone in promoting proper protein folding is well established [28-30]. It has been found that the casein aggregates into complexes ranging from a few nanometers to hundreds of nanometers in diameter [31, 32] and that surface binding may also alter the structure of casein. Casein has been used in the past on the surface of $\mathrm{SiO}_{2}$ for immobilization and induced activity of kinesin [33]. It was predicted that above a minimum casein concentration, an irreversible monolayer of casein is formed on the surface with a thickness corresponding to the size of the casein in solution [33]. Reduced adsorption of microbes (Listeria monocytogenes) due to the protection provided by surface preadsorption with milk protein has also been reported [34].

Therefore, the aim of this study was set to investigate one of the potential mechanisms of action behind the casein and whey protein effectiveness that would reduce the cellulase irreversible adsorption to lignocellulosic biomass. Analytical techniques such as Fourier transform infrared spectroscopy (FT-IR), scanning electron microscopy (SEM), and Kjeldahl and BSA protein analyses were used to determine the adsorption of whey and casein protein to biomass, and capillary electrophoresis (CE) was used to analyze the modifications in enzyme solubilization in the presence of additives.

\section{Materials and Methods}

2.1. Pretreatment of Corn Stover. Ground corn stover $(8 \mathrm{~mm}$ screen, Speedy King, Winona Attrition Mill Co., MN, USA) was pretreateds with different techniques as described in Table 1. Lime and dilute acid pretreatments of corn stover were performed according to optimized conditions reported previously by Kaar and Holtzapple [35] and Lloyd and Wyman [36], respectively. These pretreatments were performed in a 1-L Parr reactor (Parr Instrument Company, Moline, IL, USA) equipped with Rushton disc impeller rotating at $100 \mathrm{rpm}$, with pressure and temperature control. For dilute sulfuric acid pretreatment, ground corn stover was soaked in $0.98 \%$ sulfuric acid overnight at a solid loading rate of $5 \%$. The soaked corn stover in acid solution was then loaded into the reactor and treated for $40 \mathrm{~min}$ at $140^{\circ} \mathrm{C}$. The reaction was terminated by immersing the reactor in a cold water bath. Vacuum filtration with Whatman no. 2 filter paper was used to separate pretreated biomass from the liquid, and the solids were then washed with DI water until a neutral $\mathrm{pH}$ was achieved. For lime pretreatment, the ground corn stover was mixed with $0.075 \mathrm{~g} / \mathrm{g} \mathrm{Ca}(\mathrm{OH})_{2}$ at a solid loading rate of $19.5 \%$ and then heated to $120^{\circ} \mathrm{C}$ for $4 \mathrm{~h}$. The solid fraction was recovered, rinsed, and filtered as described earlier.

Alkali pretreatment was conducted according to Gupta and Lee [37]. In brief, $1 \% \mathrm{w} / \mathrm{v} \mathrm{NaOH}$ was mixed with ground corn stover to achieve a solid loading rate of $8.3 \%$ and then was heated in sealed Erlenmeyer flasks at $60^{\circ} \mathrm{C}$ for $24 \mathrm{~h}$. Solids were filtered and washed until a neutral $\mathrm{pH}$ was obtained. Extrusion pretreatment was conducted according to Karunanithy and Muthukumarappan [38] using a single screw extruder (Brabender Plasti-corder Extruder Model 
TABLE 1: Pretreatment condition of corn stover and the resulting corn stover composition.

\begin{tabular}{|c|c|c|c|c|c|}
\hline \multirow[b]{2}{*}{ Pretreatment } & \multirow[b]{2}{*}{ Condition } & \multirow[b]{2}{*}{$\begin{array}{l}\text { Pretreatment severity } \\
\qquad\left(\log R_{0}\right)^{\mathrm{f}}\end{array}$} & \multicolumn{3}{|c|}{ Yield of original components left in pretreated solids (\%) } \\
\hline & & & Glucan & Xylan & Lignin \\
\hline Untreated & NA & NA & 34.6 & 14.9 & 20.2 \\
\hline Acid & $\begin{array}{c}0.98 \% \mathrm{H}_{2}\left(\mathrm{SO}_{4}\right), 5 \% \mathrm{SL}, 140^{\circ} \mathrm{C}, \\
40 \mathrm{~min}\end{array}$ & 2.77 & $26.7-28.9$ & 1.0 & 16.4 \\
\hline Lime & $\begin{array}{c}0.075 \mathrm{~g} / \mathrm{g}^{\mathrm{a}} \mathrm{Ca}(\mathrm{OH})_{2}, 19.5 \% \mathrm{SL} \\
120^{\circ} \mathrm{C}, 5 \mathrm{~h}\end{array}$ & 2.96 & 33.5 & 10.6 & 12.3 \\
\hline Alkali & $1 \% \mathrm{NaOH}, 8.3 \% \mathrm{SL}^{\mathrm{b}}, 60^{\circ} \mathrm{C}, 24 \mathrm{~h}$ & 3.31 & $31.1-33.0$ & 11.9 & 7.3 \\
\hline Extrusion & $\begin{array}{c}90^{\circ} \mathrm{C}^{\mathrm{c}}, 180^{\circ} \mathrm{C}^{\mathrm{d}}, 180^{\circ} \mathrm{C}^{\mathrm{e}} \\
45-90 \mathrm{sec}, 1: 5 \mathrm{SL}\end{array}$ & 2.20 & $33.5-33.9$ & 14.7 & 20.2 \\
\hline AFEX & $50 \% \mathrm{SL}, 140^{\circ} \mathrm{C}, 15 \mathrm{~min}$ & 2.34 & 31.1 & 14.9 & 15.8 \\
\hline
\end{tabular}

${ }^{\mathrm{a}} \mathrm{C} \mathrm{Ca}(\mathrm{OH})_{2} / \mathrm{g}$ Biomass, ${ }^{\mathrm{b}} \mathrm{SL}$ : solid loading (biomass: $\mathrm{H}_{2} \mathrm{O}$ ), ${ }^{\mathrm{c}}$ feed zone temperature $=90^{\circ} \mathrm{C},{ }^{\mathrm{d}}$ transition zone temperature $=180^{\circ} \mathrm{C}$, ${ }^{\mathrm{e}}$ die zone temperature $=$ $180^{\circ} \mathrm{C},{ }^{\mathrm{f}} \log R_{0}=\log [$ time $\exp (H-R) / 14.75]$, where $H$ is pretreatment temperature and $R$ is a reference temperature of $100^{\circ} \mathrm{C}$.

PL2000, Hackensack, NJ, USA) with a barrel length to screw diameter ratio (L/D) of $20: 1$ and a compression ratio of $3: 1$. The moisture content of ground corn stover was adjusted to $20 \% \mathrm{wb}$ and held overnight before being manually fed into the extruder at an average rate of $16.5 \mathrm{~g} / \mathrm{min}$. While the residence time of the material in the barrel varied slightly due to the nature of the manual feeding, a mean reaction time of 45-90s was estimated. The temperatures of feed, barrel, and die zone of the extruder were held at 90, 180, and $180^{\circ} \mathrm{C}$, respectively. AFEX-pretreated biomass was provided by Michigan State University (see conditions in Table 1).

2.2. Enzymes. Celluclast $1.5 \mathrm{~L}$, with a cellulase activity of 71.7 FPU/mL, and Novozyme 188, with a $\beta$-glucosidase activity of $422.14 \mathrm{CBU} / \mathrm{mL}$ obtained from Sigma Aldrich were used as the cellulytic enzymes. Celluclast $1.5 \mathrm{~L}$ and Novozyme 188 were used at dosages of $25 \mathrm{FPU} / \mathrm{g}$ glucan and $\mathrm{CBU}:$ FPU ratio $\sim 2.5$, respectively.

2.3. Adsorption of Casein and Whey Proteins to Corn Stover Determined by FT-IR. Fourier transform infrared spectroscopy (FT-IR) was initially used to determine the casein biopolymers physical adsorption onto the corn stover. Corn stover containing $1 \%(\mathrm{w} / \mathrm{v})$ glucan prepared with different techniques according to Section 2.1 was blended in 50\% $(\mathrm{v} / \mathrm{v})$ citrate buffer $(\mathrm{pH} 4.85), 2.5 \mathrm{~g} / \mathrm{g}$ glucan of casein or skim milk, and sufficient deionized water (DI) for a total volume of $10 \mathrm{~mL}$ to achieve a $3 \%$ solid loading. Prepared test tubes (in duplicate) were incubated for $72 \mathrm{~h}$ in a shaker incubator at $50^{\circ} \mathrm{C}$ and $150 \mathrm{rpm}$. After treatment, biomass was subsequently collected with vacuum filtration, and washed with 2 times the sample volume with DI water. Collected solid residues of biomass were then scanned with Fourier transform infrared spectroscopy (Nicolet 380) with an ATR (attenuated total reflectance) accessory as described in more detail elsewhere [39]. Samples were uniformly pressed against the diamond surface with the swivel pressure tower accessory; then for each spectrum, a 150-scan interferogram was collected using single beam mode with $4 \mathrm{~cm}^{-1}$ resolution
TABLE 2: Band frequencies and assignment for protein in aqueous solution.

\begin{tabular}{lccc}
\hline Designation & $\begin{array}{c}\text { Bandwidth } \\
\left(\mathrm{cm}^{-1}\right)\end{array}$ & Assignments & Ref \\
\hline $\mathrm{H}_{2} \mathrm{O}$ & $1500-1800$ & $\mathrm{C}=\mathrm{O}$ stretching & {$[40]$} \\
Amide I & $1617-1692$ & $\mathrm{C}=\mathrm{O}$ stretching & {$[41]$} \\
Amide II & $1510-1580$ & $\mathrm{~N}-\mathrm{H}$ bending vibration & {$[41]$} \\
Amide III & $1229-1301$ & C-N stretching vibration & Mix of several displacement \\
\hline
\end{tabular}

for the region of 4000 to $500 \mathrm{~cm}^{-1}$. Prior to each analysis, a background spectrum (air) was collected and automatically corrected from the sample spectrum. Reference spectra consisted of biomass that had been incubated under similar conditions as treatment samples, with the absence of additives. Wavenumber assignments brought in Table 2 demonstrate the regions of protein (amides I-II) that could be used to evaluate the protein adsorption on biomass.

\subsection{Adsorption of Casein and Whey Proteins to Corn Stover} Determined by SEM. Scanning electron microscopy (SEM) was used to provide a more in-depth qualitative analysis of the casein adsorption onto the pretreated corn stover. To prevent redundant imaging, only pure casein (with minor whey) and extrusion pretreated biomass were used in this analysis. Extruded corn stover $(5 \% \mathrm{w} / \mathrm{v})$ was solubilized in a $50 \mathrm{~mL}$ solution of citrate buffer ( $\mathrm{pH} 4.85$ ) with $4.1 \%(\mathrm{w} / \mathrm{v})$ casein. After $72 \mathrm{~h}$ of incubation at $50^{\circ} \mathrm{C}$ and $150 \mathrm{rpm}$, biomass was separated from the solution by vacuum filtration using Whatman filter paper no.2 after being washed with 2 times the sample volume with DI water. Collected biomass was then lyophilized at $-48^{\circ} \mathrm{C}$ for $48 \mathrm{~h}$ prior to SEM analysis. The samples were gold coated for $180 \mathrm{~s}$ to help reduce sample charging typically observed on non-conductive samples. All samples were imaged under high vacuum conditions, utilizing the secondary electron detector (SED). This detector is ideal for observing fine surface morphology. Images were acquired at various areas 
throughout the samples, at a variety of magnifications from $42 \mathrm{x}$ to $19,000 \mathrm{x}$.

2.5. Adsorption of Casein and Whey Proteins to Corn Stover Determined by BSA and Kjeldahl. To quantify the amount of adsorbed protein, Kjeldahl digestion [42] and Bovine serum albumin (BSA) assays were used to determine the amount of soluble protein (casein and whey). The difference between the applied protein through casein or milk and the remaining level of protein in solution after incubation would represent the amount of bonded protein. Corn stover containing 1\% $(w / v)$ glucan prepared with different techniques according to Section 2.1 was solubilized in a total volume of 80 and $30 \mathrm{~mL}$ solution for Kjeldahl and BSA assays, respectively. The solution was comprised of $50 \%(\mathrm{v} / \mathrm{v})$ citrate buffer $(\mathrm{pH} 4.85), 2.5 \%(\mathrm{w} / \mathrm{v})$ commercial casein or skim milk, and DI water. Samples were incubated for $30 \mathrm{~min}$ at $60^{\circ} \mathrm{C}$ to maximize binding of the casein or milk proteins to lignin; this was because it was reported that the elevated temperatures enhanced the adsorption activity [43]. The temperature was then reduced to $50^{\circ} \mathrm{C}$ for $72 \mathrm{~h}$ of incubation similar to the enzymatic hydrolysis condition according to NREL protocol (With no enzymes added) [44]. Samples were collected at 24, 48, and $72 \mathrm{~h}$, centrifuged at 3,000 rpm for $5 \mathrm{~min}$, and the supernatant (biomass free) was subjected to Kjeldahl or BSA analysis in duplicates.

2.6. Cellulase Solubilization Determined by CE. To estimate the modifications in cellulase solubilization during hydrolysis of corn stover with and without preincubation with casein polymers, CE (Beckman PACE MDQ capillary electrophoresis system (Beckman Coulter, Fullerton, CA, USA) equipped with a UV detector set at $214 \mathrm{~nm}$ ) was applied as the analytical tool. Samples of extruded corn stover $(1 \% \mathrm{w} / \mathrm{v}$ glucan) were prepared in a total volume of $80 \mathrm{~mL}$ consisting of $50 \%(\mathrm{v} / \mathrm{v})$ citrate buffer $(\mathrm{pH} 4.85)$, DI water, and either $2.5 \%$ w/v casein or skim milk. Each reaction vial was incubated in a shaker bath set at $150 \mathrm{rpm}$ and $60^{\circ} \mathrm{C}$ for 30 min to maximize protein binding [9]. The temperature was then reduced to $50^{\circ} \mathrm{C}$, and $25 \mathrm{FPU}$ cellulase with 2.5 CBU : FPU of $\beta$-glucosidase was added to each vial for $72 \mathrm{~h}$ enzymatic hydrolysis. Samples were withdrawn after 24, 48, and $72 \mathrm{~h}$ of incubation and then centrifuged at 3,000 rpm for $5 \mathrm{~min}$, and the biomass-free supernatants were prepared for $\mathrm{CE}$ analysis as described in the following.

Samples were processed via CE according to the method defined by Salunke et al. [45]. In brief, pure skim milk, casein, enzymes cocktail, or hydrolyzate supernatants were diluted to $10 \mathrm{mg} / \mathrm{mL}$ protein using HPLC grade water. Separation was obtained via a $50 \mu \mathrm{m}$ bare fused silica capillary with the length of $30.2 \mathrm{~cm}$. Gel formulation in a sieving range of $10-225 \mathrm{KDa}$ was used. For estimation of protein molecular weights in the sample, the SDS-MW size standard (recombinant proteins $10-225 \mathrm{kDa}$ supplied with the ProteomeLab SDS-MW Analysis Kit) was used to calibrate the gel. $\beta$-mercaptoethanol $(5 \mu \mathrm{L})$ was added to each microfuge vial containing diluted SDS-MW size standard ( $10 \mu \mathrm{L}$ in $85 \mu \mathrm{L}$ of sample buffer). Prepared vials were heated in a water bath for $10 \mathrm{~min}$ at $90^{\circ} \mathrm{C}$. A separation at constant voltage of $15 \mathrm{KV}\left(25^{\circ} \mathrm{C}\right.$ temperature and 20 bar pressure) was performed with reverse polarity in SDS-MW gel buffer. Sample was electro kinetically introduced at $5 \mathrm{kV}$ for $20 \mathrm{~s}$. A capillary preconditioning method was run every six samples. The area of each peak and identification of each protein were found and calculated from the electropherogram.

\section{Results and Discussion}

3.1. Adsorption of Casein and Whey Proteins to Corn Stover Determined by FT-IR. FT-IR was used to demonstrate the physical adsorption of casein or skim milk proteins on biomass after $72 \mathrm{~h}$ of incubation. Figures $1(\mathrm{a})-1(\mathrm{e})$ show the IR spectra of corn stover pretreated by various methods that have been incubated with skim milk or casein. Although the protein secondary structure can be obtained from the IR spectra to quantify the modifications in enzyme structure, the IR spectra obtained in this study were used without any extra manipulations (i.e., subtraction, smoothing, or convolution) to compare the amides I and II profiles visually. It is known that water and amide I and II demonstrate IR absorption at the same regions, with water peaks appearing at $1500-1800 \mathrm{~cm}^{-1}$ and amides I and II absorbing at $1617-$ $1692 \mathrm{~cm}^{-1}$ and $1510-1580 \mathrm{~cm}^{-1}$, respectively (Table 2). The differences observed in peak shapes from samples treated with casein or milk compared to those without additives can be associated to adsorbed protein (Figures 1(a)-1(e)). IR spectra collected from aqueous buffer were included in each of Figures $1(\mathrm{a})-1(\mathrm{e})$ to demonstrate the portion of each spectrum belonging to water. FT-IR technique was also applied before to successfully estimate the protein content of the milk [46].

As it is demonstrated in Figure 1, the sign of protein adsorption can be simply observed in almost all samples. Lime-pretreated corn stover (Figure 1(b)) and AFEXpretreated CS (Figure 1(e)) showed the highest profile of amide II compared to adsorbed protein to other pretreated CSs, while alkali-pretreated samples did not show a significant increase in amides I or II regions compared to control (Figure 1(a)). These results suggest that either a lower amount of protein was adsorbed to some biomass (e.g., alkali pretreated) or the casein substructure was deformed when it adsorbed to biomass.

Ozeki et al. [33] reported that when $0.2 \mathrm{mg} / \mathrm{mL}$ of casein was introduced to $\mathrm{SiO}_{2}$, most of the casein was tightly adsorbed to the surface of $\mathrm{SiO}_{2}$, and when it was washed with casein-free buffer, only some part of the casein released from the surface. Repeated introduction of casein solution to the surface of $\mathrm{SiO}_{2}$ resulted in readsorption of casein to the surface. As a result, the author suggested that casein adsorption to $\mathrm{SiO}_{2}$ surfaces has two modes of a tightly and a weakly bound layer.

3.2. Adsorption of Casein and Whey Proteins to Corn Stover Determined by SEM. Scanning electron microscopy (SEM) was used as another surface analysis technique to demonstrate whether casein and milk proteins have any affinity to 


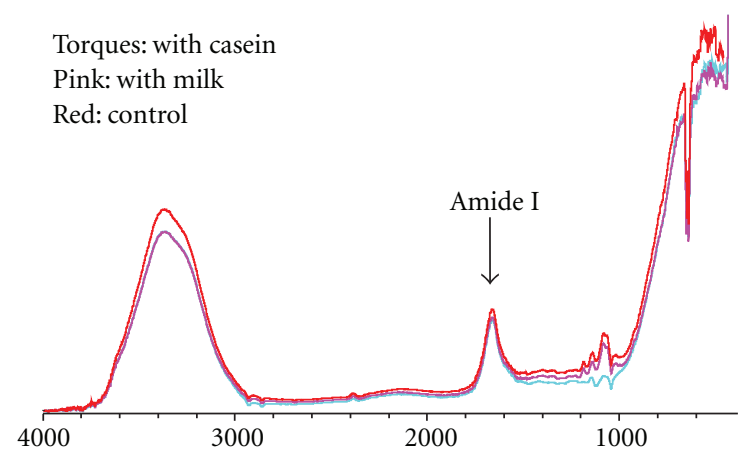

(a) Alkali pretreated CS

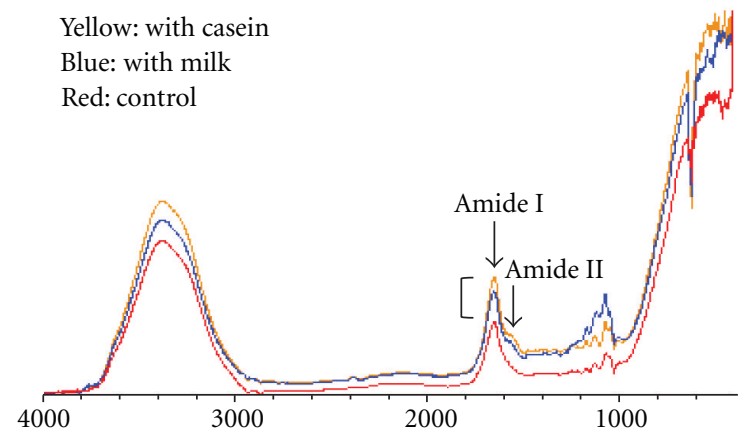

(c) DA pretreated CS

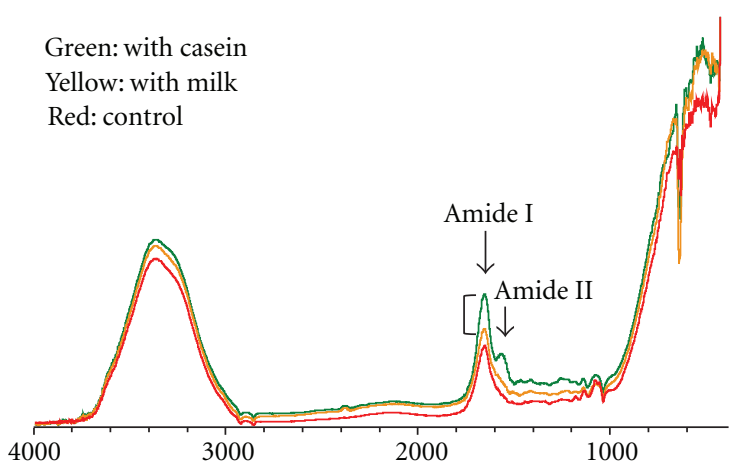

(b) Lime pretreated CS

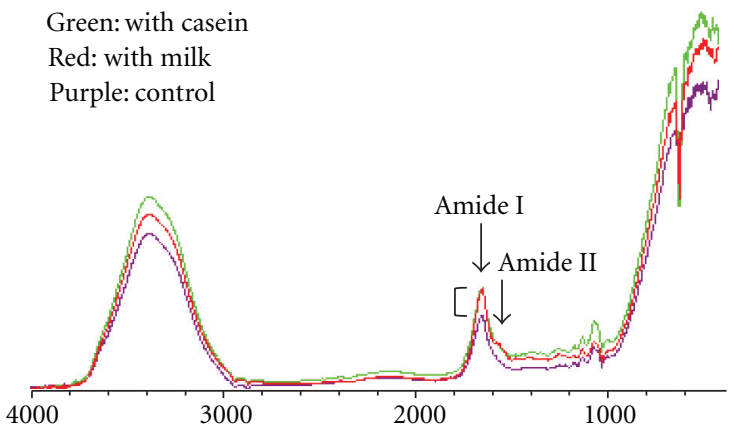

(d) Extrusion pretreated CS

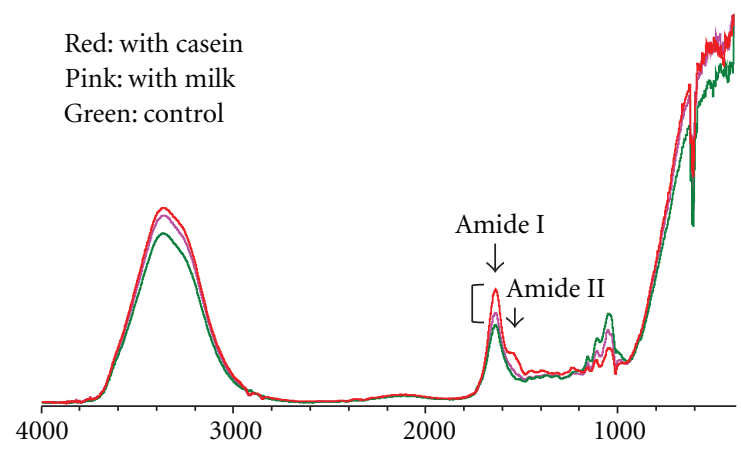

(e) AFEX pretreated CS

FIGURE 1: FTIR plots of alkali-pretreated corn stover incubated with casein and skim milk in solution of aqueous citrate buffer for $72 \mathrm{~h}$ (a); FTIR plots of lime-pretreated corn stover incubated with casein and skim milk in solution of aqueous citrate buffer for $72 \mathrm{~h}$ (b); FTIR plots of dilute acid-pretreated corn stover incubated with casein and skim milk in solution of aqueous citrate buffer for $72 \mathrm{~h}$ (c); FTIR plots of extrusion-pretreated corn stover incubated with casein and skim milk in solution of aqueous citrate buffer for $72 \mathrm{~h}$ (d); FTIR plots of AFEXpretreated corn stover incubated with casein and skim milk in solution of aqueous citrate buffer for $72 \mathrm{~h}$ (e). Bracket sign demonstrates the amount of protein adsorbed on biomass.

corn stover and the degree to which they are able to adsorb to biomass after a certain period of incubation (Figure 2). As can be observed in Figure 2, when $4.5 \% \mathrm{w} / \mathrm{v}$ of casein in citrate buffer solution of biomass was lyophilized, the casein formed a white cake with a substantial number of perforations and globules on the surface of biomass. Due to the magnification limitations of SEM, the casein micelles themselves were not shown in this study. However single casein micelles images have been taken by field-emission scanning electron microscopy and can be found in the paper of Dalgleish et al. [47]. According to their imaging results, the size of the casein micelles varies between $200 \mathrm{~nm}$ and $350 \mathrm{~nm}$, and the surface of each micelle at this magnification has been shown to conform to cylindrical or tubular structures that vary between 10 and $20 \mathrm{~nm}$ [47]. The size of the lyophilized casein globules on biomass varied between 5 and $50 \mu \mathrm{m}$ 


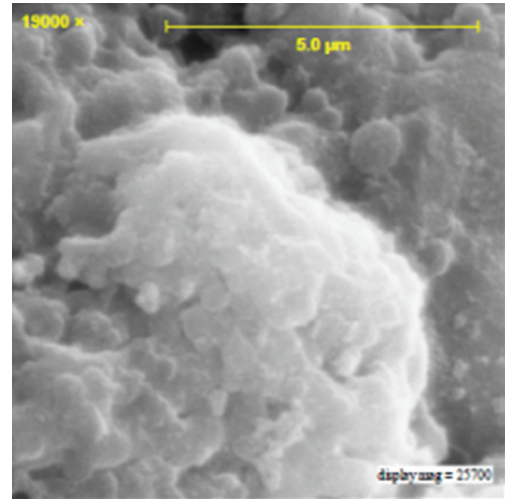

(a)

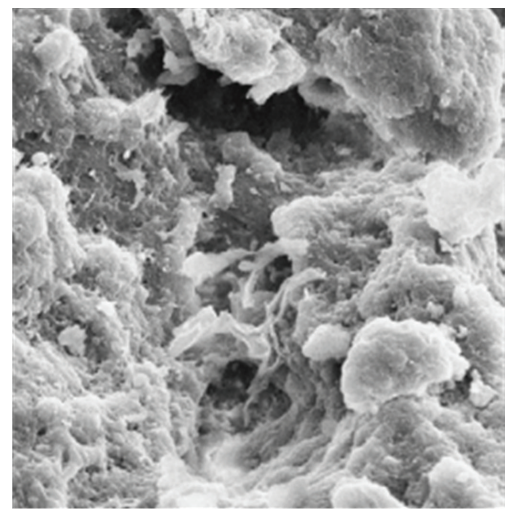

(d)

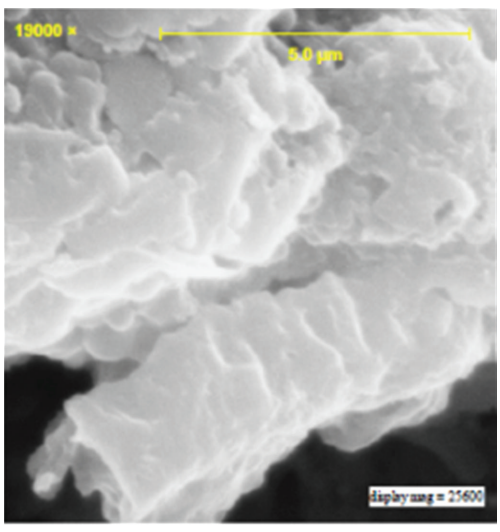

(g)

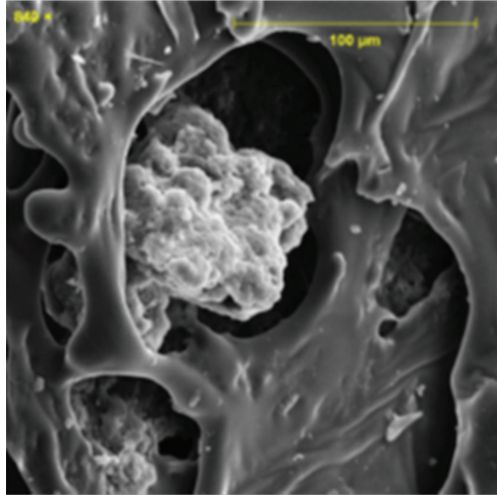

(b)

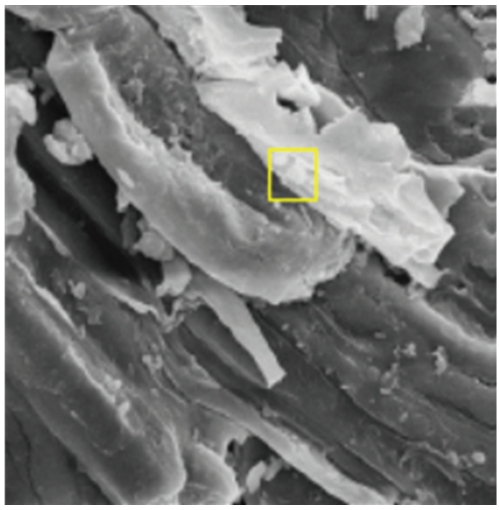

(e)

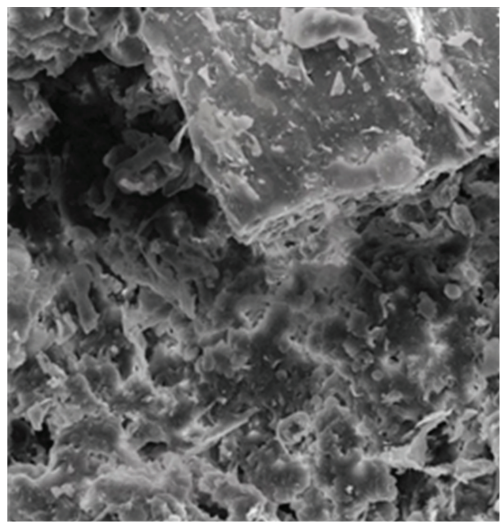

(h)

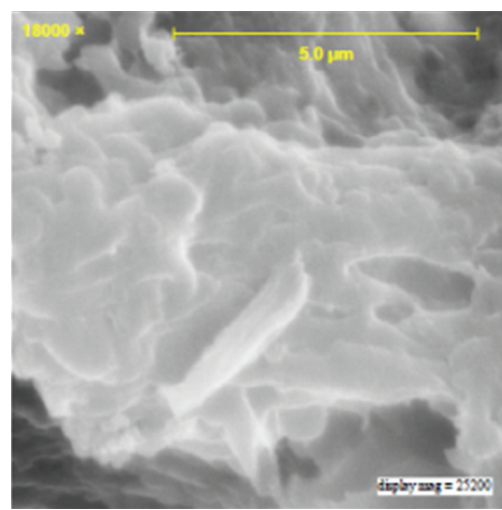

(c)

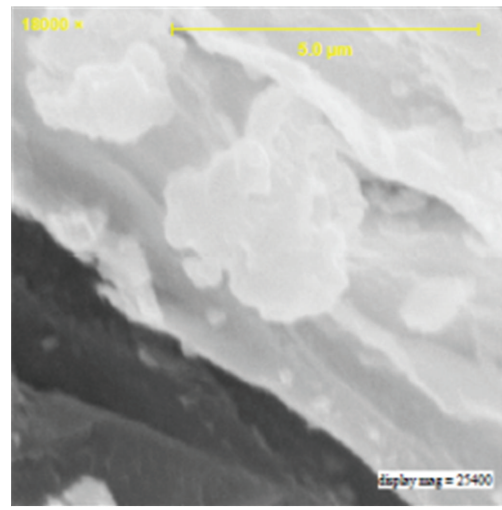

(f)

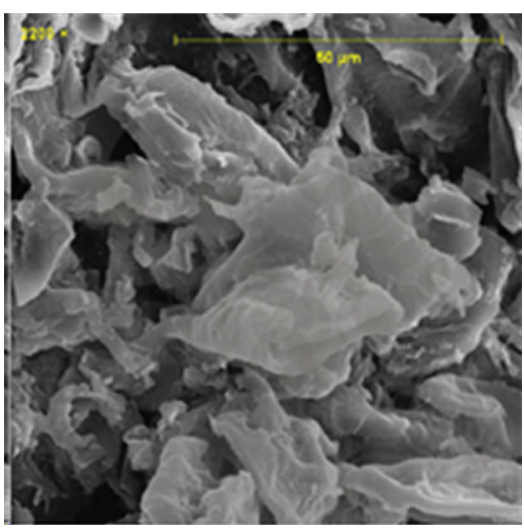

(i)

Figure 2: SEM analysis of lyophilized: $4 \% \mathrm{w} / \mathrm{v}$ casein solution in citrate buffer((a), (b), and (c)); extrusion-pretreated corn stover (8 mm) incubated for $24 \mathrm{~h}$ with $4 \% \mathrm{w} / \mathrm{v}$ casein solution of citrate buffer ((d), (e), (f), and (g)); extrusion-pretreated corn stover incubated for $24 \mathrm{~h}$ in citrate buffer only ((h), and (i)).

(Figures 2(a), 2(b) and 2(c)). Although the structure and position of casein at the time of reaction are best captured by imaging from a liquid sample, the aggregation of casein micelles at $\mathrm{pH} 4.85$ was previously reported to be observed even by naked eye [48].

Observed contrast between the two Figures 2(d) and 2(h), associated with casein treated biomass and control, respectively, can clearly demonstrate the adsorption of casein polymers to the surface of corn stover. It appears that casein initially created several layers of coating in some areas, while in other regions it adhered to the strands of biomass in a discontinuous coagulation form (Figures 2(e) and 2(f)). Interfacial studies on casein-hydrophobic surfaces for protein activations have shown that casein binds to the $\mathrm{SiO}_{2}$ surfaces by forming a tightly bound monolayer of $\beta$ casein, followed by a second loosely bound layer [49]. Tiberg et al. [50] found similar subunit interactions for casein adsorbed to silicon oxide. It is noteworthy to indicate that 
TABle 3: Comparison of soluble casein or skim milk proteins after $72 \mathrm{~h}$ of incubation with lime-, alkali-, dilute acid-, and extrusionpretreated corn stover determined with BSA assay.

\begin{tabular}{lcccccc}
\hline \multirow{2}{*}{ Pretreatment } & \multicolumn{2}{c}{ Soluble skim milk proteins (\%) } & \multicolumn{3}{c}{ Soluble casein proteins (\%) } \\
& $24 \mathrm{~h}$ & $48 \mathrm{~h}$ & $72 \mathrm{~h}$ & $24 \mathrm{~h}$ & $48 \mathrm{~h}$ & $72 \mathrm{~h}$ \\
\hline Dilute acid & 29 & $<1$ & $<1$ & 21 & $<1$ & $<1$ \\
Lime & 55 & 15 & 18 & 5.6 & 5.2 & $<1$ \\
Alkali & 90 & 22 & 14 & 65 & 3.1 & $<1$ \\
Extrusion & 92 & 25 & 10 & 55 & 8.6 & $<1$ \\
AFEX & 97 & 28 & 15 & 30 & 3.5 & $<1$ \\
Raw & 91 & $<1$ & 15 & 49 & 2.5 & $<1$ \\
\hline
\end{tabular}

we used double the casein dose that we usually apply for hydrolysis in order to clearly show the coating effect of the casein on cellulosic biomass.

\subsection{Adsorption of Casein and Whey Proteins to Corn Stover} Determined by BSA and Kjeldahl. In addition to the two surface analysis techniques (SEM and FT-IR) that were applied to illustrate the adsorption of casein or milk proteins onto corn stover, Kjeldahl and BSA protein assays were used for quantitative evaluation of the same phenomenon. Solution of aqueous citrate buffer comprised of $2.5 \% \mathrm{w} / \mathrm{v}$ casein polymer or skim milk and $1 \% \mathrm{w} / \mathrm{v}$ of corn stover $(8 \mathrm{~mm})$ were incubated together at $60^{\circ} \mathrm{C}$ for $30 \mathrm{~min}$ followed by $72 \mathrm{~h}$ of incubation at $50^{\circ} \mathrm{C}$. The amount of soluble proteins was obtained by measuring the protein left in supernatant of samples drawn after 24,48 , and $72 \mathrm{~h}$ of incubation of biomass with casein or milk and comparing that to control (aqueous buffer of casein or milk with no biomass). The difference in protein content would represent the amount of protein adsorbed onto the biomass.

The results of Kjeldahl analysis demonstrated that after $24 \mathrm{~h}$ of incubation of casein with biomass, $68.37 \%$ of casein proteins $(1.17$ to $0.37 \%(\mathrm{w} / \mathrm{v}))$ were adsorbed to the surface of biomass. Based on the compositional analysis of the milk used in the study, $2.5 \%(\mathrm{w} / \mathrm{v})$ of milk solution was projected to contain $0.87 \% \mathrm{w} / \mathrm{v}$ protein; this was also confirmed by Kjeldahl assay that was indicated to be $0.89 \% \mathrm{w} / \mathrm{v}$ protein. After $24 \mathrm{~h}$ of incubation of $1 \% \mathrm{w} / \mathrm{v}$ corn stover in milk solution, the results demonstrated that $15.7 \%$ of the milk protein was adsorbed to the biomass. According to the amount of the biomass used, an adsorption rate of 0.80 and $0.14 \mathrm{~g}$ of protein/g of biomass can be estimated for casein and milk proteins, respectively.

Another method used to evaluate the adsorption of casein or milk proteins to pretreated corn stover was BSA assay. In this assay, BSA protein of $2 \mathrm{mg} / \mathrm{mL}$ was used as reference, and the reactivity of the protein being evaluated was assumed to be comparable to that of BSA. Table 3 shows the percentage of soluble protein found after 24,48 and $72 \mathrm{~h}$ of incubation of $1 \% \mathrm{w} / \mathrm{v}$ glucan equivalent of pretreated corn stover with $2.5 \% \mathrm{w} / \mathrm{v}$ casein polymers or skim milk.

The greater adsorption of soluble casein proteins to biomass compared to milk proteins was in agreement with Kjeldahl analysis. However, Kjeldahl analysis demonstrated a slightly higher protein adsorption compared to what was obtained with BSA analysis. The adsorption of milk protein to biomass was found to vary between 1.12 and $73.9 \%$ whereas casein adsorption varied between 37.5 and $93.4 \%$ after $24 \mathrm{~h}$ of incubation. These results suggest that casein proteins have a much higher affinity for corn stover compared to proteins in milk. Moreover, the affinity of proteins varies depending on the pretreated corn stover used. This might have been due to the differences in particle size, surface area, and chemical structure originating from different pretreatment techniques.

While casein has shown a stronger earlier affinity to pretreated corn stover compared to milk protein, adsorption of both milk and casein approached $100 \%$ by $72 \mathrm{~h}$ of incubation. Recently, Zhang et al. [51] reported that increasing the incubation time of lignocellulosic substrate with PEG 4000 from $0-2 \mathrm{~h}$ increased the amount of adsorbed PEG. They suggested that increasing the incubation time provided PEG with additional opportunity to interweave into the biomass structure and create a denser hydration layer on the exterior surface. As a result, the denser layer of polymer can provide a greater steric hindrance for the enzyme from the nonspecific sites.

The extensive adsorption of casein onto biomass observed in this research study was not unanticipated in light of the widespread application of casein as glue for adhesion of wood particles. Moreover, the adsorption of $\beta$-casein to a silica-aqueous solution interface or bimodal PEG brushes and many other supports has been reported in the past [32, $52,53]$. Based on the prior arts, $\beta$-casein creates a densely packed monolayer on surfaces via hydrophobic interaction and adsorption of its highly charged $\mathrm{N}$-terminal to the pseudophases [52].

3.4. Cellulase Solubilization Determined by CE. Evaluating a specific protein in a mixture of proteins has always been challenging, since methods that use the total nitrogen value cannot distinguish between specific proteins. Analytical methods that can distinguish between proteins include CE, SDS-Page gel electrophoresis, and size exclusion chromatography. However, one of the concerns with these methods is that the peak associated with the protein of interest may overlap with other proteins in the mixture. We selected CE to evaluate the modifications in enzyme adsorption under the effect of casein and milk's preadsorption to biomass. In this trial, the relative amount of enzyme substructure 


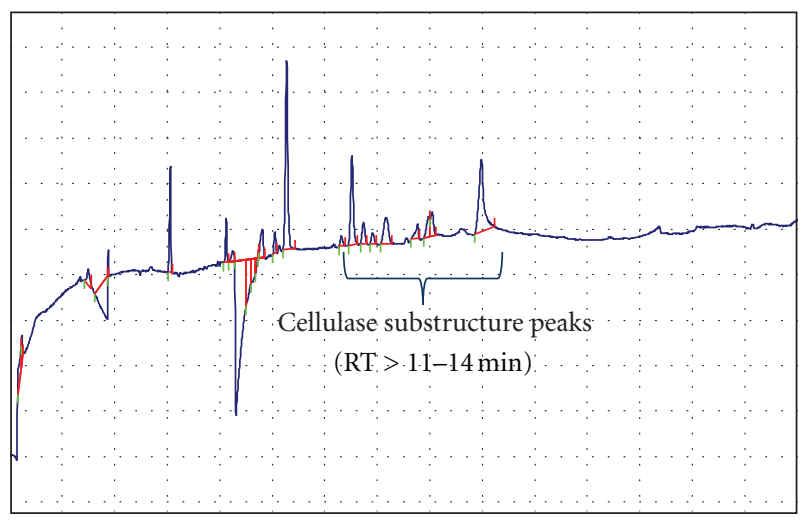

(a)

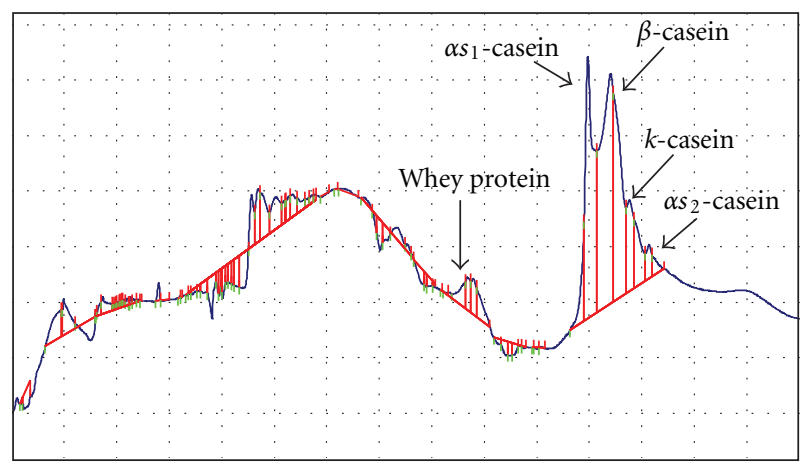

(b)

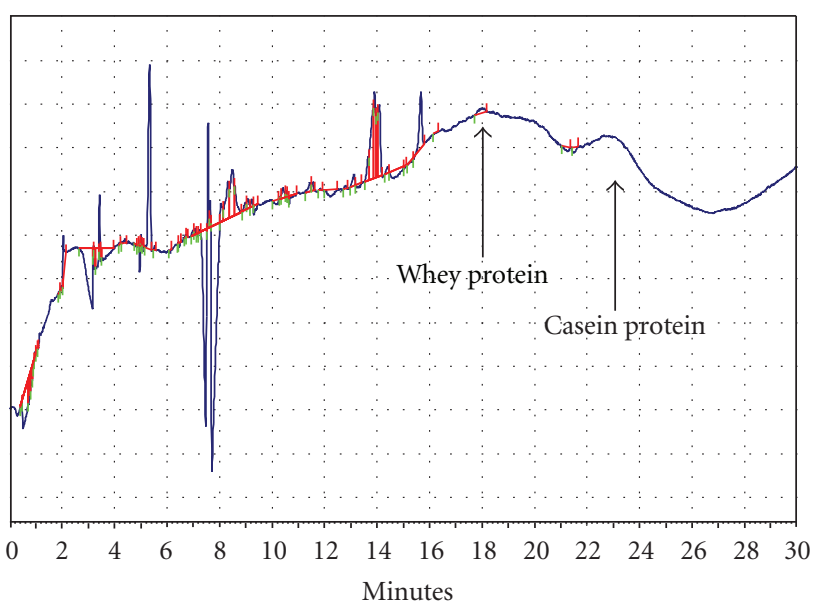

(c)

FIGURE 3: Capillary electrophoresis plots of pure cellulase diluted in HPLC grade water (a); commercial casein diluted in HPLC grade water (b);skim milk powder diluted in HPLC grade water (c).

in control (enzymatic hydrolysis without additive) and treatment samples (with casein and milk) were compared with each other. Using CE, we were able to differentiate between peaks associated with enzyme and those associated with casein and whey proteins. To locate the characteristic peaks for each of these compounds, separate solutions of HPLC-grade water containing each of these compounds were prepared and processed via capillary electrophoresis.
TABLE 4: Reduction in one of the mono-component of soluble cellulase in hydrolyzate of corn stover preadsorbed with casein or skim milk compared to control (no additive) determined by CE.

\begin{tabular}{lc}
\hline Sample condition & Reduction in soluble cellulase (\%) \\
\hline No additive $24 \mathrm{~h}$ & $97.1 \pm 1.1$ \\
No additive $72 \mathrm{~h}$ & $99.5 \pm 0.0$ \\
With casein $24 \mathrm{~h}$ & $32.8 \pm 6.0$ \\
With casein $72 \mathrm{~h}$ & $0.0 \pm 0.0$ \\
With skim milk $24 \mathrm{~h}$ & $82.8 \pm 6.0$ \\
With skim milk $72 \mathrm{~h}$ & $74.8 \pm 0.8$
\end{tabular}

*Standard errors of the mean reported after \pm .

As can be observed in Figures 3(a)-3(c), the CE analysis of individual samples of cellulase, casein, and milk proteins resulted in characteristic peaks for each material. The cellulase sample (Figure 3(a)) contained peaks at 10.5, 13, 14.5, 16, and $18 \mathrm{~min}$. Commercial casein (Figure 3(b)) consisted of casein substructures (as labeled), along with minute amounts of whey protein. As can be observed, peaks for $k$-casein appeared at $24.2 \mathrm{~min}, \alpha s_{2}$-casein at $23.2 \mathrm{~min}, \beta$ casein at $23.8 \mathrm{~min}, \alpha s_{1}$-casein at $22.0 \mathrm{~min}$, and whey protein at $16-18 \mathrm{~min}$. As it is apparent, the peaks of casein and whey proteins associated with $\sim 20-24$ and $\sim 18$ min (Figures 3 (b) and $3(\mathrm{c})$ ) did not overlap with peaks of cellulase. Therefore, retention times of $>11-14,20-28$, and $16-18 \mathrm{~min}$ were used to track the cellulase, casein, and skim milk proteins, respectively.

According to the results (Figure 4(a)), the relative cellulase concentration in corn stover samples that were enzymatically hydrolyzed without the use of any polypeptide additives (casein or skim milk) was smaller than that in samples preincubated with casein or milk. This suggests that cellulase was either adsorbed to corn stover or other hydrophobic surfaces in reaction site or has been degraded. However, when corn stover was treated with casein or skim milk, the specific subunit of cellulase at 12.8 min was significantly increased compared to control (Figures 4 (b) and $4(\mathrm{c})$ ).

In the first $24 \mathrm{~h}$ of reaction, the majority of cellulase was adsorbed to biomass, during which the amount of one of the cellulase mono-component was reduced in solution by $97.1 \% \pm 1.1$. Application of casein and milk reduced the adsorption to $32.9 \% \pm 6.0$ and $82.8 \% \pm 6.0$, respectively (Table 4). After $72 \mathrm{~h}$ of hydrolysis the amount of soluble cellulase adsorption was further reduced to $74.9 \% \pm 0.8$ for milk-treated samples and to less than a quantifiable amount for casein-treated corn stover.

It was found that the reduction in casein and whey proteins after $72 \mathrm{~h}$ compared to that of $24 \mathrm{~h}$ was correlated with the increase in cellulase solubilization. These results suggest the steric barrier role for casein and milk, which prevents from the cellulase nonproductive adsorption to biomass. Similar effects were obtained from the application of nonionic surfactants and polymers such as Triton X-100, Tween 20 and 80, PEG 4000 and 6000, and many others [9$11,54]$ in which the adsorption of surfactants to surface of 


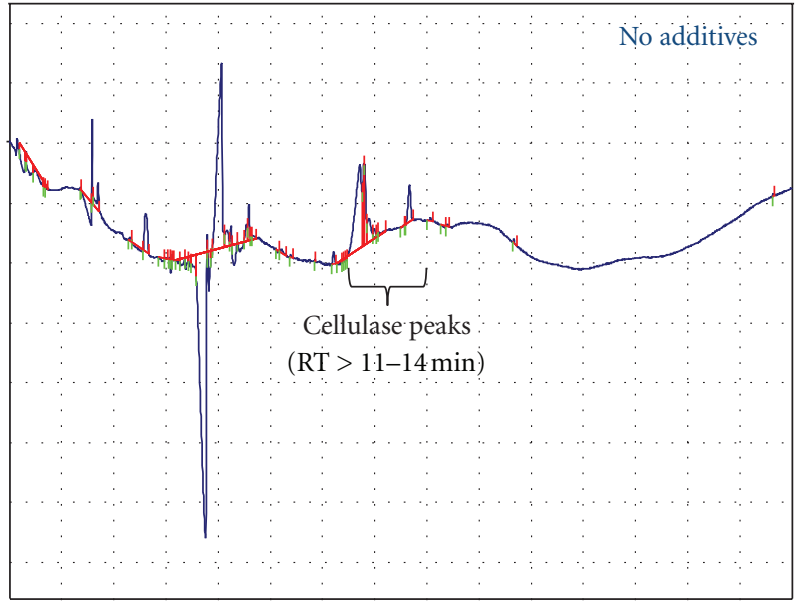

(a)

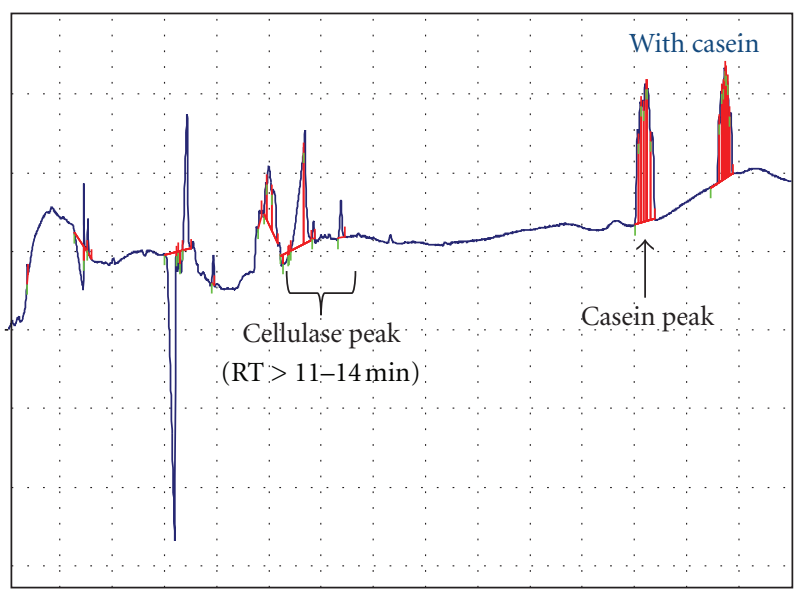

(b)

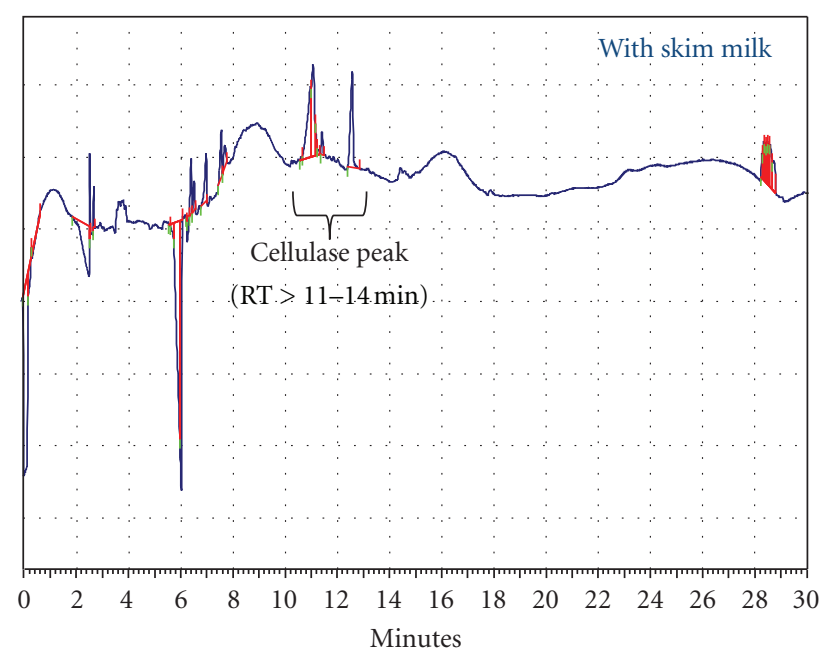

(c)

FIgURE 4: Capillary electrophoresis plots of supernatant from the solution of corn stover hydrolyzed for $24 \mathrm{~h}$ with cellulase (no additives) (a); supernatant from the solution of casein-treated corn stover hydrolyzed for $24 \mathrm{~h}$ with cellulase (b); supernatant from the solution of skim milk-treated corn stover hydrolyzed for $24 \mathrm{~h}$ with cellulase (c). biomass was demonstrated to improve the cellulase activity and increase the enzyme solubilization $[20,43,55]$.

It was reported that polymers adsorbed to surfaces can effectively use the relationship between electrostatic and steric interactions in order to control the adsorption and desorption of proteins of interest [56]. These fundamental findings have been applied in pharmaceutical, surface chemistry, and many other fields to serve as the basis for the design of controlled-release devices $[57,58]$. Whole casein or the substructures of casein were used onto microtubule motility assays to reserve the kinesin functionality. It was found that the adsorbed casein bilayer improves the activity of kinesin, by one of the tightly bound casein layer anchoring the kinesin, while the second loosely bound layer of casein improves the position of kinesin for interaction with microtubules [59].

\section{Conclusion}

The cost of cellulase is a major barrier in biomass conversion process, necessitating new techniques to maintain cellulase activity for an extended period of time to reduce cellulase utilization and facilitate cellulase recycling. Casein was found to be an effective biopolymer that can reduce enzyme deactivation. One of the mechanisms of action associated with casein effectiveness on the induction of cellulase activity during conversion of lignocellulosic biomass was investigated using several techniques. As a result, it was found that with no additive, the majority of one of the cellulase monocomponent, $97.1 \pm 1.1$, was irreversibly adsorbed to corn stover within the first $24 \mathrm{~h}$ of hydrolysis. However application of casein or skim milk reduced the cellulase adsorption to $32.9 \% \pm 6.0$ and $82.8 \% \pm 6.0$, respectively. The preadsorption of casein proteins to biomass was demonstrated to be much higher than skim milk protein, and the adsorption of either varied based on the pretreatment of biomass used. Amide profile of the adsorbed casein or skim milk proteins to biomass suggested that perhaps some of the proteins substructures are deformed at the time of adsorption. The results of this study suggest that steric barrier provided by adsorbed casein and whey proteins on lignocellulosic biomass may induce the cellulase activity by prohibition of cellulase adsorption to nonproductive sites of the biomass. Other impacts of biomass-adsorbed protein on cellulase should be further studied.

\section{Conflict of Interests}

The authors of this paper have no conflict of interest to declare.

\section{Acknowledgments}

The authors thank the Agricultural Experiment Station, South Dakota State University, and the North Central Sun Grant Center, Brookings, South Dakota, and U.S. Department of Energy, Golden, CO, Grant no. DE-FG3608GO88073 for funding, facilities, equipment, and supplies. 
The authors would also like to thank Dr. LIoyd Metzger and Mr. Salunke Prafulla for accommodation and guiding the analysis of capillary electrophoresis.

\section{References}

[1] M. J. Taherzadeh and K. Karimi, "Acid-based hydrolysis process for ethanol from lignocellulosc materials: a review," Bioresour, vol. 2, pp. 472-499, 2007.

[2] Z. Yue, C. Teater, Y. Liu, J. MacLellan, and W. Liao, "A sustainable pathway of cellulosic ethanol production integrating anaerobic digestion with biorefining," Biotechnology and Bioengineering, vol. 105, no. 6, pp. 1031-1039, 2010.

[3] L. Olsson and B. Hahn-Hägerdal, "Fermentation of lignocellulosic hydrolysates for ethanol production," Enzyme and Microbial Technology, vol. 18, no. 5, pp. 312-331, 1996.

[4] D. Klein-Marcuschamer, P. Oleskowicz-Popiel, B. A. Simmons, and H. W. Blanch, "The challenge of enzyme cost in the production of lignocellulosic biofuels," Biotechnology and Bioengineering, vol. 109, no. 4, pp. 1083-1087, 2011.

[5] S. K. Khanal and B. Lamsal, Bioenergy and Biofuel Production: Some Prospective, 2010.

[6] W. K. Kaar and M. T. Holtzapple, "Benefits from Tween during enzymatic hydrolysis of corn stover," Biotechnology and Bioengineering, vol. 59, pp. 419-427, 1998.

[7] T. P. Gunjikar, S. B. Sawant, and J. B. Joshi, "Shear deactivation of cellulase, exoglucanase, endoglucanase, and $\beta$-glucosidase in a mechanically agitated reactor," Biotechnology Progress, vol. 17, no. 6, pp. 1166-1168, 2001.

[8] M. H. Kim, S. B. Lee, D. D. Y. Ryu, and E. T. Reese, "Surface deactivation of cellulase and its prevention," Enzyme and Microbial Technology, vol. 4, no. 2, pp. 99-103, 1982.

[9] A. D. Eckard, K. Muthukumarappan, and W. Gibbons, "Pretreatment of extruded corn stover with polyethylene glycol to enhance enzymatic hydrolysis: optimization, kinetics, and mechanism of action," BioEnergy Research, vol. 5, no. 2, pp. 424-438, 2011.

[10] J. B. Kristensen, J. Börjesson, M. H. Bruun, F. Tjerneld, and H. Jørgensen, "Use of surface active additives in enzymatic hydrolysis of wheat straw lignocellulose," Enzyme and Microbial Technology, vol. 40, no. 4, pp. 888-895, 2007.

[11] T. Eriksson, J. Börjesson, and F. Tjerneld, "Mechanism of surfactant effect in enzymatic hydrolysis of lignocellulose," Enzyme and Microbial Technology, vol. 31, no. 3, pp. 353-364, 2002.

[12] B. Yang and C. E. Wyman, "BSA treatment to enhance enzymatic hydrolysis of cellulose in lignin containing substrates," Biotechnology and Bioengineering, vol. 94, no. 4, pp. 611-617, 2006.

[13] Z. Xiao, X. Zhang, D. J. Gregg, and J. N. Saddler, "Effects of sugar inhibition on cellulases and $\beta$-glucosidase during enzymatic hydrolysis of softwood substrates," Applied Biochemistry and Biotechnology, vol. 115, no. 1-3, pp. 1115-1126, 2004.

[14] Q. Qing, B. Yang, and C. E. Wyman, "Xylooligomers are strong inhibitors of cellulose hydrolysis by enzymes," Bioresource Technology, vol. 101, no. 24, pp. 9624-9630, 2010.

[15] T. H. Kim, Y. Y. Lee, C. Sunwoo, and J. S. Kim, "Pretreatment of corn stover by low-liquid ammonia recycle percolation process," Applied Biochemistry and Biotechnology, vol. 133, no. 1, pp. 41-57, 2006.

[16] Y. M. Zhu, T. H. Kim, Y. Y. Lee, R. G. Chen, and R. T. Elander, "Enzymatic production of xylooligosaccharides from corn stover and corn cobs treated with aqueous ammonia,"
Applied Biochemistry and Biotechnology, vol. 130, no. 1-3, pp. 586-598, 2006.

[17] E. Ximenes, Y. Kim, N. Mosier, B. Dien, and M. Ladisch, "Deactivation of cellulases by phenols," Enzyme and Microbial Technology, vol. 48, no. 1, pp. 54-60, 2011.

[18] E. Hoshino and A. Tanaka, "Enhancement of enzymatic catalysis of bacillus amyloliquefaciens $\alpha$-amylase by nonionic surfactant micelles," Journal of Surfactants and Detergents, vol. 6, no. 4, pp. 299-303, 2003.

[19] E. M. K. Hedin, P. Høyrup, S. A. Patkar, J. Vind, A. Svendsen, and K. Hult, "Implications of surface charge and curvature for the binding orientation of Thermomyces lanuginosus lipase on negatively charged or zwitterionic phospholipid vesicles as studied by ESR spectroscopy," Biochemistry, vol. 44, no. 50, pp. 16658-16671, 2005.

[20] D. J. Seo, H. Fujito, and A. Sakoda, "Effects of a non-ionic surfactant, Tween 20, on adsorption/desorption of saccharification enzymes onto/from lignocelluloses and saccharification rate," Adsorption, vol. 17, no. 5, pp. 813-822, 2011.

[21] T. Maobing, X. Zhang, M. Paice, P. McFarlane, and J. N. Saddler, "Effect of surfactants on separate hydrolysis fermentation and simultaneous saccharification fermentation of pretreated lodgepole pine," Biotechnology Progress, vol. 25, no. 4, pp. 1122-1129, 2009.

[22] O. G. Berg, Y. Cajal, G. L. Butterfoss et al., "Interfacial activation of triglyceride lipase from Thermomyces (Humicola) lanuginosa: kinetic parameters and a basis for control of the lid," Biochemistry, vol. 37, no. 19, pp. 6615-6627, 1998.

[23] S. S. Helle, S. J. B. Duff, and D. G. Cooper, "Effect of surfactants on cellulose hydrolysis," Biotechnology and Bioengineering, vol. 42, no. 5, pp. 611-617, 1993.

[24] T. Cserháti, E. Forgács, and G. Oros, "Biological activity and environmental impact of anionic surfactants," Environment International, vol. 28, no. 5, pp. 337-348, 2002.

[25] M. J. Taherzadeh and K. Keikhosro, "Enzyme-based hydrolysis proceses for ethanol from lignocellulosic material, a review," BioResources, vol. 2, pp. 707-738, 2007.

[26] J. Wu and L. K. Ju, "Enhancing enzymatic saccharification of waste newsprint by surfactant addition," Biotechnology Progress, vol. 14, no. 4, pp. 649-652, 1998.

[27] A. D. Eckard, K. Muthukumarappan, and W. Gibbons, "Enhanced bioethanol production from pretreated corn stover via multi-positive effect of casein micelles," Bioresource Technology, 2012.

[28] J. Bhattacharyya and K. P. Das, "Molecular chaperone-like properties of an unfolded protein, $\alpha(\mathrm{s})$ - casein," Journal of Biological Chemistry, vol. 274, no. 22, pp. 15505-15509, 1999.

[29] J. D. Wang, M. D. Michelitsch, and J. S. Weissman, "GroELGroES-mediated protein folding requires an intact central cavity," Proceedings of the National Academy of Sciences of the United States of America, vol. 95, no. 21, pp. 12163-12168, 1998.

[30] P. E. Morgan, T. M. Treweek, R. A. Lindner, W. E. Price, and J. A. Carver, "Casein proteins as molecular chaperones," Journal of Agricultural and Food Chemistry, vol. 53, no. 7, pp. 26702683, 2005.

[31] K. W. Ruettimann and M. R. Ladisch, "Casein micelles: structure, properties and enzymatic coagulation," Enzyme and Microbial Technology, vol. 9, no. 10, pp. 578-589, 1987.

[32] C. Phadungath, "Casein micelle structure: a concise review," Songklanakarin Journal of Science and Technology, vol. 27, pp. 201-212, 2005.

[33] T. Ozeki, V. Verma, M. Uppalapati et al., "Surface-bound casein modulates the adsorption and activity of kinesin on 
SiO2 surfaces," Biophysical Journal, vol. 96, no. 8, pp. 33053318, 2009.

[34] H. Al-Makhlafi, J. McGuire, and M. Daeschel, "Influence of preadsorbed milk proteins on adhesion of Listeria monocytogenes to hydrophobic and hydrophilic silica surfaces," Applied and Environmental Microbiology, vol. 60, no. 10, pp. 35603565, 1994.

[35] W. E. Kaar and M. T. Holtzapple, "Using lime pretreatment to facilitate the enzymic hydrolysis of corn stover," Biomass and Bioenergy, vol. 18, no. 3, pp. 189-199, 2000.

[36] T. A. Lloyd and C. E. Wyman, "Combined sugar yields for dilute sulfuric acid pretreatment of corn stover followed by enzymatic hydrolysis of the remaining solids," Bioresource Technology, vol. 96, no. 18, pp. 1967-1977, 2005.

[37] R. Gupta and Y. Y. Lee, "Pretreatment of corn stover and hybrid poplar by sodium hydroxide and hydrogen peroxide," Biotechnology Progress, vol. 26, no. 4, pp. 1180-1186, 2010.

[38] C. Karunanithy and K. Muthukumarappan, "Response surface methodology for optimization of corn stover pretreatment using an extruder," Biological Engineering, vol. 3, no. 1, pp. 7395, 2010.

[39] S. P. S. Chundawat, B. Venkatesh, and B. E. Dale, "Effect of particle size based separation of milled corn stover on AFEX pretreatment and enzymatic digestibility," Biotechnology and Bioengineering, vol. 96, no. 2, pp. 219-231, 2007.

[40] A. Dong, P. Huang, and W. S. Caughey, "Protein secondary structures in water from second-derivative amide i infrared spectra," Biochemistry, vol. 29, no. 13, pp. 3303-3308, 1990.

[41] J. Kong and S. Yu, "Fourier transform infrared spectroscopic analysis of protein secondary structures," Acta Biochimica et Biophysica Sinica, vol. 39, no. 8, pp. 549-559, 2007.

[42] R. D. M. Hooi, R. L. Barbano, D. Bradley et al., Standard Methods For the Examination of Dairy Products, American Public Health Association, Washington DC, 2004.

[43] J. Börjesson, M. Engqvist, B. Sipos, and F. Tjerneld, "Effect of poly(ethylene glycol) on enzymatic hydrolysis and adsorption of cellulase enzymes to pretreated lignocellulose," Enzyme and Microbial Technology, vol. 41, no. 1-2, pp. 186-195, 2007.

[44] M. Selig, N. Weiss, and Y. Ji, Enzymatic Saccharification of Lignocellulosic Biomass March Laboratory Analytical Procedure (LAP), 2008.

[45] P. Salunke, C. Marella, and L. E. Metzger, "Use of capillary gel electrophoresis for quantification of individual milk proteins in ultra- and microfiltration retentate," Journal of Dairy Science, vol. 94, article 58, supplement 1, 2011.

[46] Y. Etzion, R. Linker, U. Cogan, and I. Shmulevich, "Determination of protein concentration in raw milk by mid-infrared fourier transform infrared/attenuated total reflectance spectroscopy," Journal of Dairy Science, vol. 87, no. 9, pp. 27792788, 2004.

[47] D. G. Dalgleish, P. A. Spagnuolo, and H. D. Goff, "A possible structure of the casein micelle based on high-resolution fieldemission scanning electron microscopy," International Dairy Journal, vol. 14, no. 12, pp. 1025-1031, 2004.

[48] J. Satulovsky, M. A. Carignano, and I. Szleifer, "Kinetic and thermodynamic control of protein adsorption," Proceedings of the National Academy of Sciences of the United States of America, vol. 97, no. 16, pp. 9037-9041, 2000.

[49] G. Fragneto, R. K. Thomas, A. R. Rennie, and J. Penfold, "Neutron reflection study of bovine $\beta$-casein adsorbed on OTS self-assembled monolayers," Science, vol. 267, no. 5198, pp. 657-660, 1995.
[50] F. Tiberg, T. Nylander, T. J. Su, J. R. Lu, and R. K. Thomas, " $\beta$-casein adsorption at the silicon oxide-aqeous solution interface," Biomacromolecules, vol. 2, no. 3, pp. 844-850, 2001.

[51] Y. Zhang, Y. Zhang, and L. Tang, "Effect of PEG4000 on cellulase catalysis in the lignocellulose saccharification processes," Journal of Chemical Technology and Biotechnology, vol. 86, no. 1, pp. 115-120, 2011.

[52] M. Lee, S. P. Kyung, C. Chung, and H. Kim, "QCM study of $\beta$ casein adsorption on the hydrophobic surface: effect of ionic strength and cations," Bulletin of the Korean Chemical Society, vol. 25, no. 7, pp. 1031-1035, 2004.

[53] N. Ngadi, J. Abrahamson, C. Fee, and K. Morison, "QCM-D study of $\beta$-casein on silicate-PEG surfaces," Journal of Applied Sciences, vol. 10, no. 24, pp. 3343-3348, 2010.

[54] A. D. Eckard, K. Muthukumarappan, and W. Gibbons, "Modeling of pretreatment condition of extrusion pretreated prairie cordgrass and corn stover with polyoxyethylen (20) sorbitan monolaurate," Applied Biochemistry and Biotechnology, vol. 167, no. 2, pp. 377-393.

[55] J. Li, S. Li, C. Fan, and Z. Yan, "The mechanism of polyethylene glycol (PEG) 4000 effect on enzymatic hydrolysis of lignocellulose," Colloids and Surfaces B: Biointerfaces, vol. 89, pp. 203-210, 2011.

[56] M. M. R. Talukder, T. Takeyama, Y. Hayashi et al., "Improvement in enzyme activity and stability by addition of low molecular weight polyethylene glycol to sodium bis(2-ethylL-hexyl)sulfosuccinate/isooctane reverse micellar system," Applied Biochemistry and Biotechnology, vol. 110, no. 2, pp. 101-112, 2003.

[57] M. Haider, Z. Megeed, and H. Ghandehari, "Genetically engineered polymers: status and prospects for controlled release," Journal of Controlled Release, vol. 95, no. 1, pp. 1-26, 2004.

[58] E. Leonard, V. Turitto, T. Vincent, and L. Vroman, Blood in Contact With Natural and Artificial Surfaces, vol. 2, The New York Academy of Sciences, New York, NY, USA, 1987.

[59] V. Verma, W. O. Hancock, and J. M. Catchmark, "The role of casein in supporting the operation of surface bound kinesin," Journal of Biological Engineering, vol. 2, article 14, 2008. 

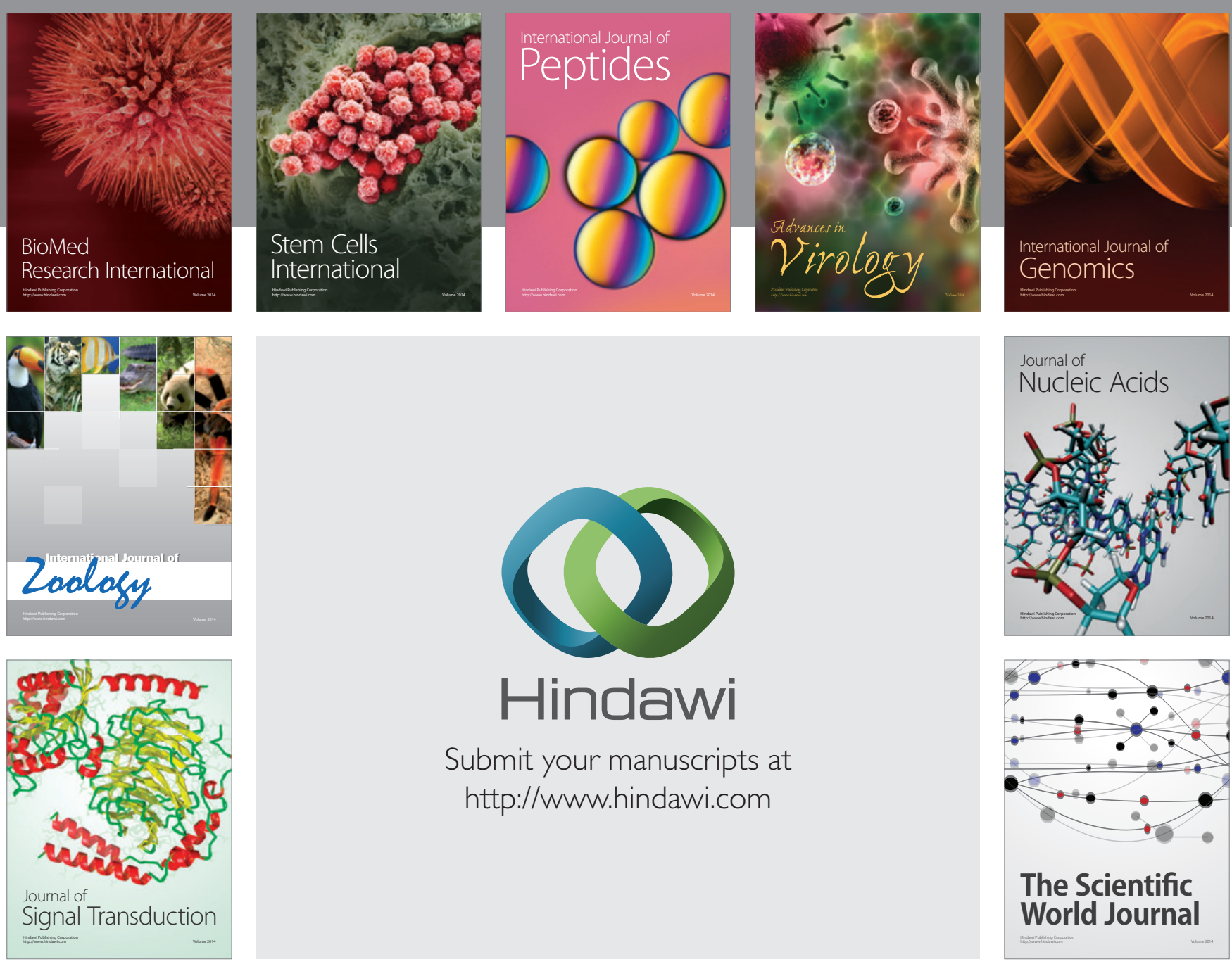

Submit your manuscripts at

http://www.hindawi.com
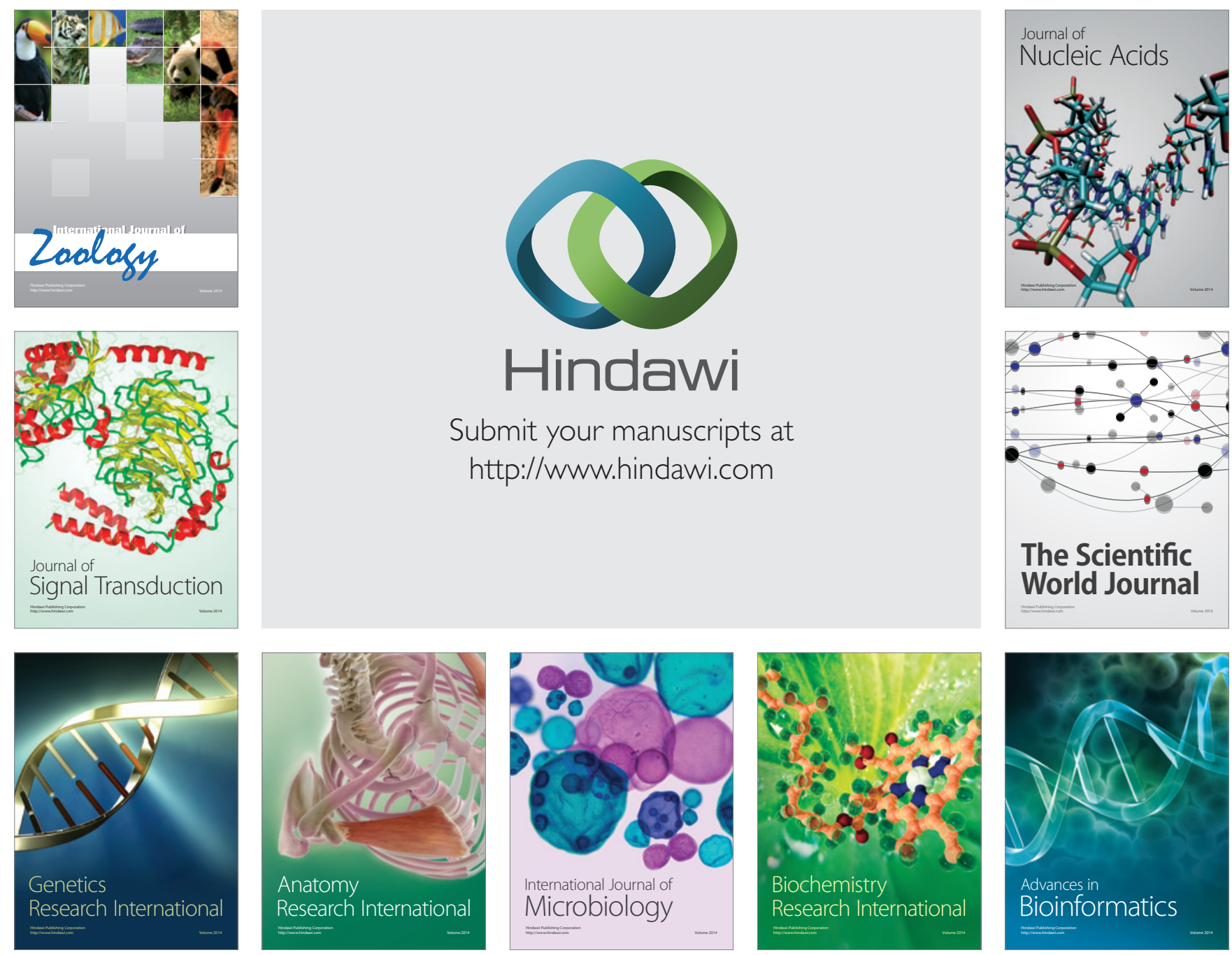

The Scientific World Journal
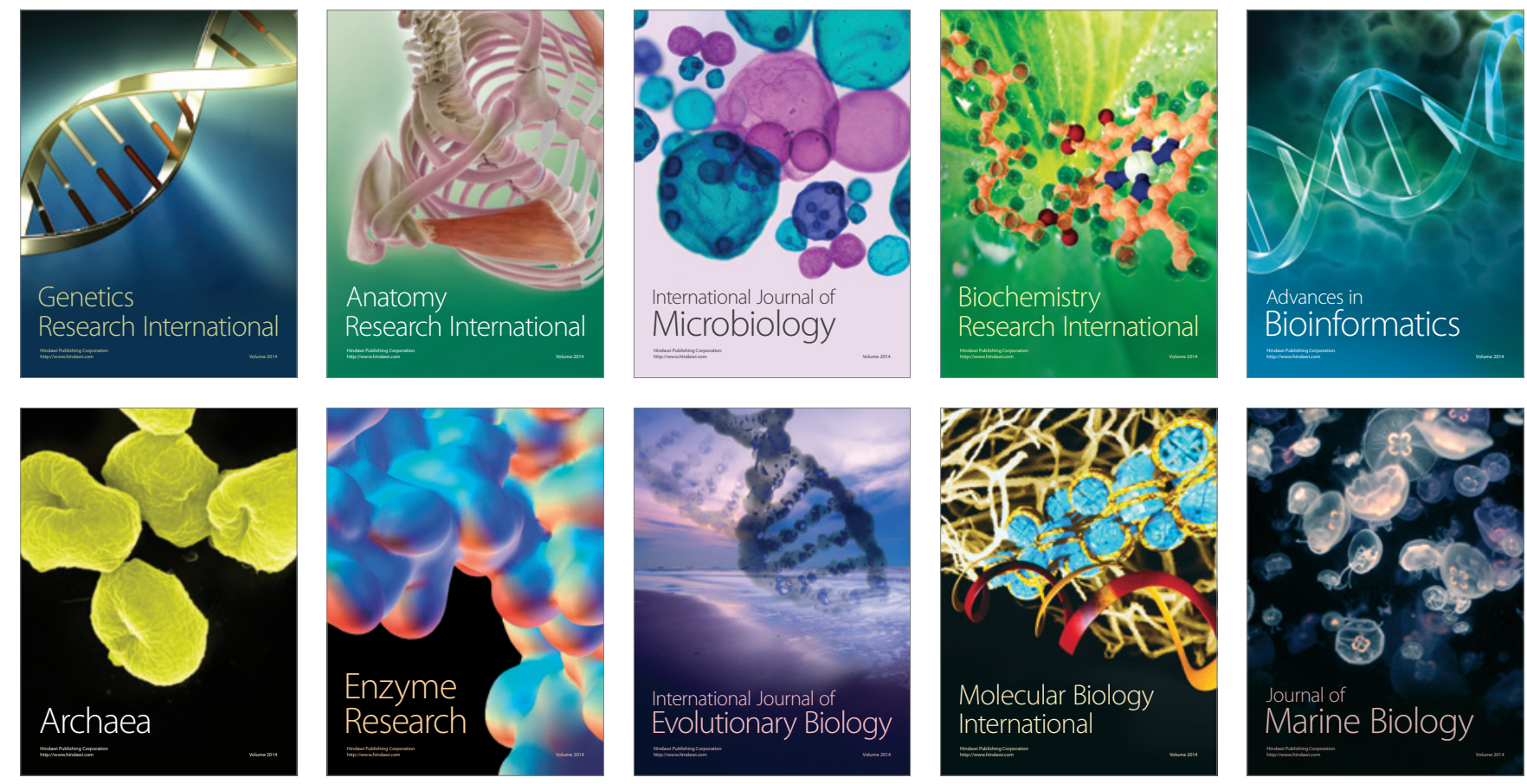